\title{
Examining of implementations of early childhood teachers working at preschools in Ankara in music education
}

\author{
Özlem ERSOY ${ }^{*}$
}

\author{
Zeynep DERE $^{* *}$
}

\begin{abstract}
This research was conducted to examine music education applications and the problems with of early childhood teachers working at preschools in Ankara city center. The study included randomly selected 212 early childhood teachers from 166 schools. When data were analyzed, the followings were determinated; $57,08 \%$ of teachers do not use instruments during the activities; 55,66 $\%$ of teachers do not have enough instruments for each child in their classroom. Data also suggested that; teachers do not do musical activities primarily; $37,45 \%$ of teachers primarily ask children to imitate objects, such as animal or etc. in order to support creative dance activities. Consequently, the study suggested that teachers apply the activities which they are knowledgeable but their knowledge is insufficient. Therefore, the teachers need in-service education in different areas of music.
\end{abstract}

Keywords: Early childhood teachers, Music education, Rhtym, Creative dance, Teaching song, Sound listening and differentiation.

\footnotetext{
*Assist. Prof. Dr., Gazi University, Vocational Education Faculty, Department of Child Development Education, Ankara, Turkey.E-mail:ozlemer@gazi.edu.tr

Res. Assist., Gazi University, Vocational Education Faculty, Department of Child Development Education, Ankara, Turkey. E-mail:zeynepdere@gazi.edu.tr
} 


\section{SUMMARY}

Purpose and Significance: This research was conducted to examine music education applications and the problems with of early childhood teachers working at preschools in Ankara city center.

Method: The study included randomly selected 212 early childhood teachers from 166 schools. Data were gathered via questionaires. The questionaire was developed from literature search and presented to 7 university academic lecturers who are the experts in their fields. Based on the suggestions, the questionaire was revised. Demographic informations of teachers were presented on tables with disturibution of frequency and percentage. The answers about the variables of sub- purpose of the research were analyzed with disturubution level and percentage and listed in terms of the importance. Assesments were made in terms of the cumulative percents and listed on the tables.

Results: When data were analyzed, the followings were determinated; $57,08 \%$ of teachers do not use instruments during the activities; $55,66 \%$ of teachers do not have enough instruments for each child in their classroom. Data also suggested that; teachers do not do musical activities primarily; 37 , $45 \%$ of teachers primarily ask children to imitate objects, such as animal or etc. in order to support creative dance activities. 35,20\% of teachers first give the rhytm for the rhytm activities and ask children run, walk and jump with the rhtym. In addition, teachers expressed that they do not have any problem with sound listening and discrimination, rhytm activities and creative dance activities. When the teachers' level of work satisfaction was analyzed, the results showed that their satisfaction levels were medium.

Discussion and Conclusion: Consequently, the study suggested that teachers apply the activities which they are knowledgeable but their knowledge is insufficient. Therefore, the teachers need in-service education in different areas of music. 


\section{Ankara İl Merkezindeki Anasınıflarında Görev Yapan Öğretmenlerin Müzik Eğitimi Kapsamında Yaptıkları Uygulamaların İncelenmesi}

\author{
Özlem ERSOY*
}

\author{
Zeynep DERE $^{* *}$
}

ÖZ. Bu araştırma, Ankara il merkezindeki anasınıflarında görev yapan öğretmenlerin, müzik eğitimi uygulamalarını ve karşılaştıkları sorunları saptamak amacıyla planlanmıştır. Araştırmaya tabakalı rasgele örnekleme yöntemi ile seçilen 166 okuldan toplam 212 öğretmen dahil edilmiştir. Veriler, anket formu aracılı̆̆ıyla toplanmıştır. Elde edilen veriler incelendiğinde; Öğretmenlerin \% 57,08' inin etkinlikler sırasında çalgı kullanmadığı, \% 55,66' sının sınıfında her çocuğa yetecek kadar çalg1 bulunmadığı saptanmıştır. Öğretmenlerin müzikli hikaye çalışmalarını birinci öncelikle yaptırmadıkları, \% 37, 45' inin yaratıcı dans çalışmalarında ise birinci öncelikle çocuklardan, verilen bir müzik eşliğinde çeşitli nesne ve hayvanları taklit ederek yaratıcı dans etmelerini desteklediklerini belirtmiştir. Ancak öğretmenler; müzik eğitimi konusunda bildikleri etkinlikleri uygulamakta, farklı uygulamalara yönelmemektedirler. $\mathrm{Bu}$ nedenle öğretmenlerin farklı etkinlikler konusunda da hizmet içi eğitimi programları ile desteklenmesi kaçınılmaz görülmektedir.

Anahtar Sözcükler: Okul öncesi öğretmeni, Müzik eğitimi, Ritim, Yaratıcı dans, Şarkı öğretimi, Ses dinleme ve ayırt etme.

\footnotetext{
Yrd. Doç. Dr., Gazi Üniversitesi, Mesleki Eğitim Fakültesi, Çocuk Gelişimi Eğitimi Bölümü, Ankara, Türkiye. E-posta: ozlemer@gazi.edu.tr

** Arş. Gör., Gazi Üniversitesi, Mesleki Eğitim Fakültesi, Çocuk Gelişimi Eğitimi Bölümü, Ankara, Türkiye. E-posta: zeynepdere@gazi.edu.tr
} 


\section{GİRIŞ̧}

Bireyin müziksel gelişimi doğum öncesi dönemde başlamakta ve bütün yaşamı boyunca sürekli ilerleme göstererek devam etmektedir. Müziksel gelişim evrensel gelişim ilkelerinden bağımsız düşünülmemektedir. Müziksel gelişim, genel gelişim özelliklerine göre biçimlenmekte, ilerlemekte, çocuğun genel gelişimi ile birlikte işleyen ve birbiri içerisinde yer alan bir süreci içermektedir (Yıldız, 2003: 190). Müziksel zeka, melodi ve ritim tonlarını algılayabilme yeteneğini içermektedir. Bu yönleri ile dil gelişimini ve mantıksal- matematiksel zekayı beslemektedir. Örneğin: piyanoda tuşlara basarak bir melodiyi yaratma gibi deneyimlerle çocuk uygulama, analiz, sentez ve değerlendirme gibi yüksek düzeyde düşünme becerilerinin tamamını geliştirmektedir (Isenberg ve Jalongo, 1997: 131). Nitekim erken yaşlarda müzik çalgıları çalan çocukların bilişsel zeka seviyelerinin daha iyi olduğu görülmektedir. (Schlaug ve arkadaşları, 2005: 224). Müzik dinlemenin ve müzik derslerinin çocukların zihinsel gelişimine bir etkisinin olup olmadığı sürekli tartışılmış ve müzik dinlemenin bilişsel testlerde öğrencinin başarısını arttırdığı saptanmıştır (Schellenberg, 2005: 317). Çocuklara sunulan çeşitli müzik aktiviteleri, çocukların dili öğrenme becerilerine yardımcı olmaktadır (Wilson ve Roehmann, 1987; Tselentis, 2000: 25). Şark1 söyleme ve dinleme yoluyla çocuğun kelime hazinesi gelişmekte aynı yapı içinde belirli kelimelerin sürekli tekrarlanması kelimelere anlam verilebilmesini kolaylaştırmaktadır (Özkardeş, 2005:266).

Okul öncesinde müzik etkinliği, günlük program içerisinde göze çarpan önemli bir saattir. Şarkı söyleme, ritim tutma ve müziğe göre hareket etme gibi aktiviteler tipik grup aktiviteleridir. Müzik etkinliği yoluyla ortak katılımlar ve etkileşimli öğrenmeler olmaktadır (Kostelnik ve arkadaşları, 2004: 100).

Okul öncesi eğitimde, müzik programının dört temel öğesi bulunmaktadır; bunlar müziği dinleme, hareketlerle müziğe eşlik etme, müzik yapma ve iyi müziği ayırt etmedir (Henniger, 1999: 419).

Müzik etkinliklerinin içeriğinde yer alması gereken unsurlar ise şunlardır:

- Dinleme deneyimleri

- Dikkate dayalı etkinlikler, yüksek, alçak, hızlı ve yavaş ritimler, tekrarlar, tonlar

- Sabit vuruşları, melodisi veya kelimeleri yakalanabilen, el çırpılan, sallanılan ve coşkulu olan marşlar

- Müziğin içinde yer alan koordineli hareketler

- Yaratıcilığı ve hayal gücünü destekleyen etkinlikler

- Çalgilar (Machado, 2003: 67). 
Okul öncesi eğitimcileri, müzik çalışmaları konusunda cesur olmalıdır. Sınıfta kendiliğinden ortaya çıkan fırsatlar değerlendirilmelidir. Çocukların bireysel farklılıkları olduğu unutulmamalıdır. Özel yeteneği olan çocuklar fark edildiğinde zaman aileyle ve profesyonel kişilerle iş birliğine girilmelidir. Tüm çocukların etkin katılımı sağlanmalıdır (Artan, 2003: 274). Müzik eğitiminin, sadece öğretmenin çocuklara sunacağ 1 deneyimlerden oluşmamasına dikkat edilmelidir. Çocuklar, gün içerisinde müzik materyallerini keşfetme ve kendi müziklerini yaratma konusunda cesaretlendirilmelidir (Hirsh, 2004: 207).

Müzik eğitiminde hedefe ulaşabilmek için okul öncesi öğretmenin birtakım yollar izlemesi gerekmektedir:

- Her sınıfta bir müzik köşesi ve bu köşede çok kaliteli/ işlevsel çalgılar bulunmalıdır,

- Çocukları müziğe karşı güdüleyici hikayeler anlatılmalı, canlandırmalar yapılmalıdır

- Kelimeler melodik bir şekilde söylenmeli, çocuğun her an melodi ve ritimden keyif alması sağlanmalıdır,

- Programın diğer etkinliklerinde müziğin nasıl kullanılabileceği araştırılmalıdır,

- Sınıf içerisinde her zaman müzik dinletisi yapılmalıdır,

- Ebeveynler arasında çalg1 çalabilenler var ise okula davet edilmelidir,

- Müzik alanında uzman kişilerden, çocuklar için özel projeler yapmaları istenmeli ve proje boyunca desteklerinden yararlanılmalıdır (Wilson, 2006: 152),

- Çocukların yakın çevre kültürlerinin müzikleri ve dünya müzik kültürlerini tanımaları için doğup büyüdükleri, üzerinde yaşadıkları toprakların müziğinden başlayarak farklı kültürlerin eserleri sınıfta sergilenmelidir, (Çetin, 2006: 65),

- Farklı kültür müzikleri yapan müzisyenler sınıfa davet edilmeli ve performansları dinlenip ardından dinleyiciye ne mesajlar vermeye çalıştıkları ve dinlerken neler hissettikleri tartışılmalıdır (Eliason ve Jenkins, 2003: 153),

- Çok kültürlü müzik etkinliklerini planlarken, uluslararası ses kayıtları ve müziklerin, değişik ülkelerin oyunları ve dansları için kostümleri sınıfa temin edilmelidir (Taylor, 1999: 262),

- Öğretmenler, çocukların ilgisini çekebilmek için vücut dilini de kullanarak şarkıları söylemelidir,

- Değişik danslar yapmaları sağlanarak çocukların yaratıcılıkları desteklenmelidir (Machado, 2003: 61). 
Okul öncesi öğretmenleri "Okul Öncesi Müzik Öğretim Yöntemleri” konusunda da yeterli olmalıdır (Gürgen: 2006: 92). Bu yöntemlerden faydalanamayan öğretmen adayları, meslek yaşamlarında müzik eğitimi sırasında ne yapacaklarını bilememekte ve müzik eğitimi, öğretmen ve çocuklar için sıkıcı hale dönüşebilmektedir. Ülkemizde okul öncesi öğretmenlerinin bu konuda ne düzeyde oldukları ve hangi konularda sorun yaşadıklarını gösteren çalışmalar ise oldukça sınırlıdır.

$\mathrm{Bu}$ araştırma, Ankara il merkezindeki anasınıflarında görev yapan öğretmenlerin, müzik eğitimi uygulamalarını ve karşılaştıkları sorunları saptamak amaciyla planlanmıştır.

\section{YÖNTEM}

\section{Araştırma Modeli}

$\mathrm{Bu}$ araştırma, konunun alt amaçlarına uygun olarak hazırlanmış anket formunun kullanıldığı betimsel bir araştırmadır (Sümbüloğlu ve Sümbüloğlu, 1998: 43).

\section{Evren}

Ankara il merkezinde bulunan Milli Eğitim Bakanlı̆̆ı'na bağlı ilköğretim okullarının anasınıflarında ve bağımsız anaokullarında görev yapan öğretmenler araştırmanın evrenini oluşturmaktadır.

\section{Örneklem}

Araştırmanın örneklemini, Ankara il merkezindeki okulların bulundukları ilçelere göre tabakalı rasgele örnekleme yöntemi ile seçilen 166 okuldan toplam 212 öğretmen oluşturmuştur.

\section{Verilerin Toplanması}

Araştırmanın örneklem grubunu oluşturan anasınıfı öğretmenlerine ulaşmak için Ankara İl Milli Eğitim Müdürlüğü' nden gerekli izinler alınmıştır ve örnekleme dahil edilmiş olan okullardaki görev yapan öğretmenlere çalışmanın amacı anlatılmış ve gönüllü olan öğretmenlere hazırlanan anket formu uygulanarak veriler toplanmıştır. 


\section{Veri Toplama Aracı}

Veriler, anket formu aracılığıyla toplanmıștır. Literatür taraması sonucunda oluşturulan anket formu, okul öncesinde müzik eğitimi ve drama alanında uzman 7 öğretim elemanının görüşlerine sunulmuştur. Alınan öneriler doğrultusunda 38 sorudan oluşan anket formu hazırlanmıştır.

\section{Verilerin Analizi}

$\mathrm{Bu}$ araştırmadan elde edilen veriler, SPSS 15.0 paket programında değerlendirilmiştir. Değişkenlere ilişkin frekans ve yüzde dağılımları hesaplanmış ve tablolar halinde sunulmuştur. Önem sırasına ilişkin değerlendirmeler ise ağırlıklı toplamlar yardımı ile yapılmış olup ağırlığına göre tercih edilen cevaplar 1' den 3'e kadar sıralanmış ve tablolara dökülmüş̧ür.

\section{BULGULAR}

Ankara il merkezindeki anasınıflarında görev yapan 212 öğretmenden elde edilen bulgular aşağıda yer almaktadır.

Tablo 1. Ö $\breve{g r e t m e n l e r i n ~ C i n s i y e t l e r i n e ~ G o ̈ r e ~ D a g ̆ ı l ı m ı ~}$

\begin{tabular}{llcc}
\hline Öğretmenlerin & & N & \% \\
\hline \multirow{2}{*}{ Cinsiyeti } & Erkek & 9 & 4,25 \\
& Kadın & 203 & 95,75 \\
\cline { 2 - 4 } & Toplam & 212 & 100,00 \\
\hline
\end{tabular}

Araştırmaya katılan öğretmenlerin \% 95,75'i kadın, \% 4,25 ise erkektir.

Tablo 2. Öğretmenlerin Ĕ̆itim Durumlarına Göre Dağılımı

\begin{tabular}{llcc}
\hline Öğretmenlerin & & N & \% \\
\hline \multirow{4}{*}{ Ĕ̆itim Durumu } & Meslek yüksek okulu & 27 & 12,73 \\
& Lisans & 175 & 82,55 \\
& Yüksek lisans & 10 & 4,72 \\
\cline { 2 - 4 } & Toplam & 212 & 100,00 \\
\hline
\end{tabular}

Öğretmenlerin \% 82,55' i lisans, \% 12,73' ü meslek yüksek okulu ve \% 4,72 'si ise yüksek lisans mezunudur. 
Tablo 3. Öğretmenlerin Müzik Ĕ̆itimi Konusunda Hizmet İçi Ĕ̆itime Gereksinim Duyma Durumlarının Dă̆ılımı

\begin{tabular}{llcc}
\hline Öğretmenlerin Müzik Eğitimi Konusunda & $\mathbf{N}$ & \% \\
\hline \multirow{2}{*}{$\begin{array}{l}\text { Hizmet içi eğitime gereksinim } \\
\text { duyma durumu }\end{array}$} & $\begin{array}{l}\text { Gereksinim } \\
\text { Duyuyorum }\end{array}$ & 171 & 80,66 \\
& $\begin{array}{l}\text { Gereksinim } \\
\text { Duymuyorum }\end{array}$ & 41 & 19,34 \\
\cline { 2 - 4 } & Toplam & 212 & 100,00 \\
\hline
\end{tabular}

Öğretmenlerin \% 80,66' s1 müzik eğitimi ile ilgili hizmet içi eğitime gereksinim duyduklarını, \% 19,34' ü ise müzik eğitimi ile ilgili hizmet içi eğitime gereksinim duymadıklarını belirtmişlerdir.

Tablo 4. Öğretmenlerin Müzik Etkinliklerinde Çalgı Kullanma Durumlarına Göre

\begin{tabular}{llcc}
\multicolumn{4}{c}{ Dă̆ılımı } \\
\hline Ö̆̆retmenlerin & N & \% \\
\hline \multirow{3}{*}{$\begin{array}{l}\text { Müzik etkinlikleri sırasında çalgı kullanma } \\
\text { durumu }\end{array}$} & Kullanıyor & 91 & 42,92 \\
& Kullanmıyor & 121 & 57,08 \\
\cline { 2 - 4 } & Toplam & 212 & 100,00 \\
\hline
\end{tabular}

Öğretmenlerin müzik etkinlikleri sırasında çalgı kullanma durumları incelendiğinde, \% 57,08' i müzik etkinlikleri sırasında çalgı kullanmadığını, $\%$ 42,92' si ise çalgı kullandı̆̆ını belirtmiştir.

Tablo 5. Öğretmenlerin Sınıflarında Müzik Köşesi Bulunma Durumlarına Göre Dă̆llımı

\begin{tabular}{llcc}
\hline Öğretmenlerin & & $\mathbf{N}$ & $\%$ \\
\hline \multirow{2}{*}{$\begin{array}{l}\text { Sinıflarında müzik köşesi bulunma } \\
\text { durumu }\end{array}$} & Bulunuyor & 198 & 93,40 \\
& Bulunmuyor & 14 & 6,60 \\
\cline { 2 - 4 } & Toplam & 212 & 100,00 \\
\hline
\end{tabular}

Tablo 5 incelendiğinde, öğretmenlerin \% 93,40' ının sınıfında bir müzik köşesi bulunurken, \% 6,60’1nda bulunmamaktadır.

Tablo 6. Öğretmenlerin Sınıflarındaki Müzik Köşesinde Yer Alan Çalgıların $\operatorname{Dağılımı~(N:~212)~}$

\begin{tabular}{lllll}
\hline Müzik Köşesinde Yer Alan & \multicolumn{3}{c}{ Var } & \multicolumn{3}{c}{ Yok } \\
\cline { 2 - 5 } Çalgilar & $\mathrm{S}$ & $\%$ & $\mathrm{~S}$ & $\%$ \\
\hline Ritim çubuğu & 124 & 58,49 & 88 & 41,51 \\
Ksilofon & 80 & 37,74 & 132 & 62,26 \\
Zil & 145 & 68,40 & 67 & 31,60 \\
Metalofon & 47 & 22,17 & 165 & 77,83 \\
\hline
\end{tabular}




\begin{tabular}{lllll}
\hline Tef & 182 & 85,85 & 30 & 14,15 \\
Davul & 147 & 69,34 & 65 & 30,66 \\
Parmak zilleri & 89 & 41,98 & 123 & 58,02 \\
Kastanyet & 30 & 14,15 & 182 & 85,85 \\
Kum kağıdı blokları & 1 & 0,47 & 211 & 99,53 \\
Marakas & 200 & 94,34 & 12 & 5,66 \\
Ses kutusu & 25 & 11,79 & 187 & 88,21 \\
Glockenspiel & 2 & 0,94 & 210 & 99,06 \\
Çelik üçgen & 89 & 41,98 & 123 & 58,02 \\
\hline
\end{tabular}

Öğretmenlerin sınıflarındaki müzik köşesinde bulunan çalgılar incelendiğinde, \% 94,34' ünde marakas, \% 85,85' inde tef, \% 69,34' ünde davul, \% 68,40' 'nda zil, \% 58,49' unda ritim çubuğu, \% 41,98' inde parmak zilleri ve çelik üçgen, \% 37,74' ünde ksilofon, \% 22,17' sinde metalofon, \% 14,15 ' inde kastanyet, \% 11,79' unda ses kutuları bulunmaktadır. Bunların yanı sıra öğretmenlerin sadece \% 0,94' ünün sınıfında glockensipel, \% 0,47' sinde ise kum kağıdı blokları bulunmaktadır.

Tablo 7. Öğretmenlerin Sınıflarındaki Çalgıların Çocuk Sayısına Göre Yeterli Olma Durumuna İlişkin Görüşlerinin Dă̆ılımı

\begin{tabular}{lcc}
\hline Sinıftaki Çalgılar & $\mathbf{N}$ & $\mathbf{\%}$ \\
\hline Yeterli & 94 & 44,34 \\
Yetersiz & 118 & 55,66 \\
Toplam & 212 & 100,00 \\
\hline
\end{tabular}

Öğretmenlerin \% 44,34' ünün sınıfında her çocuğa yetecek kadar çalg1 bulunurken, \% 55,66'sının sınıfında her çocuğa yetecek sayıda çalgı bulunmamaktadır.

Tablo 8. Öğretmenlerin Sınıflarında Ses Dinleme ve Ayırt Etme Çalışmalarını Yapma Biçimlerinin Öncelik Sırasına Göre Dă̆ılımı

\begin{tabular}{|c|c|c|c|c|c|c|c|c|c|c|c|}
\hline \multirow{2}{*}{$\begin{array}{l}\text { Öğretmenlerin Sınıflarında } \\
\text { Ses Dinleme ve Ayırt Etme } \\
\text { Çalışmalarını Yapma } \\
\text { Biçimleri }\end{array}$} & \multicolumn{2}{|c|}{ 1.Öncelik } & \multicolumn{2}{|c|}{ 2.Öncelik } & \multicolumn{2}{|c|}{ 3.Öncelik } & \multicolumn{2}{|c|}{ Toplam } & \multicolumn{2}{|c|}{$\begin{array}{c}\text { A ğırlıklı } \\
\text { Toplam }\end{array}$} & \multirow[t]{2}{*}{$\begin{array}{l}\text { Öncelik } \\
\text { Sirası* }\end{array}$} \\
\hline & $\mathrm{N}$ & $\%$ & $\mathrm{~N}$ & $\%$ & $\mathrm{~N}$ & $\%$ & $\mathrm{~N}$ & $\%$ & $\mathrm{~N}$ & $\%$ & \\
\hline $\begin{array}{l}\text { Çocuklara çevredeki doğal } \\
\text { sesleri (araba sesi, sokaktaki } \\
\text { gürültüler vb) dinletip bu } \\
\text { seslerin kaynağını soruyorum } \\
\text { Çocuklara değişik çalgıların } \\
\text { seslerini dinletip hangi } \\
\text { çalgılara ait olduğunu } \\
\text { soruyorum. } \\
\text { Çocuklara ince ve kalın } \\
\text { sesler dinletip bunların nasıl } \\
\text { sesler olduğunu soruyorum. } \\
\text { Çeşitli ses efektleri (hayvan, } \\
\text { doğa, eşya sesleri vb.) } \\
\text { dinletip bu seslerin ne sesleri }\end{array}$ & 105 & 62,13 & 44 & 72,13 & 11 & 47,37 & 169,0 & 100,00 & 117 & 10,14 & 4 \\
\hline
\end{tabular}




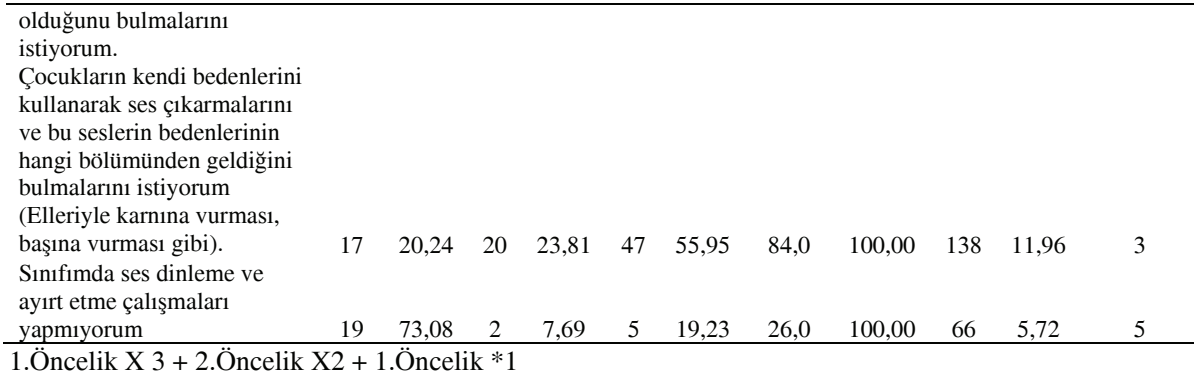

1.Öncelik X $3+2$.Öncelik X2 + 1.Öncelik *1

Öğretmenlerin \% 36,74' ü ses dinleme ve ayırt etme çalışmalarında 1. öncelikli olarak çocuklara çevredeki doğal sesleri (araba sesi, sokaktaki gürültüler vb) dinletip bu seslerin kaynağını sorduklarını, \% 30,33' ü 2 . öncelikli olarak çeşitli ses efektleri (hayvan, doğa, eşya sesleri vb.) dinletip çocuklardan bu seslerin ne sesleri olduğunu bulmalarını istediklerini, \% 11,96' sı ise 3. öncelikli olarak çocukların kendi bedenlerini kullanarak ses çıkarmalarını (elleriyle karnına vurması, başına vurması gibi) ve bu seslerin bedenlerinin hangi bölümünden geldiğini bulmalarını istediklerini belirtmişlerdir.

Tablo 9. Öğretmenlerin Sınıflarında Ses Dinleme ve Ayırt Etme Çalışmalarını Yaparken Karşılaștıkları Sorunların Öncelik Sırasına Göre Dağılımı

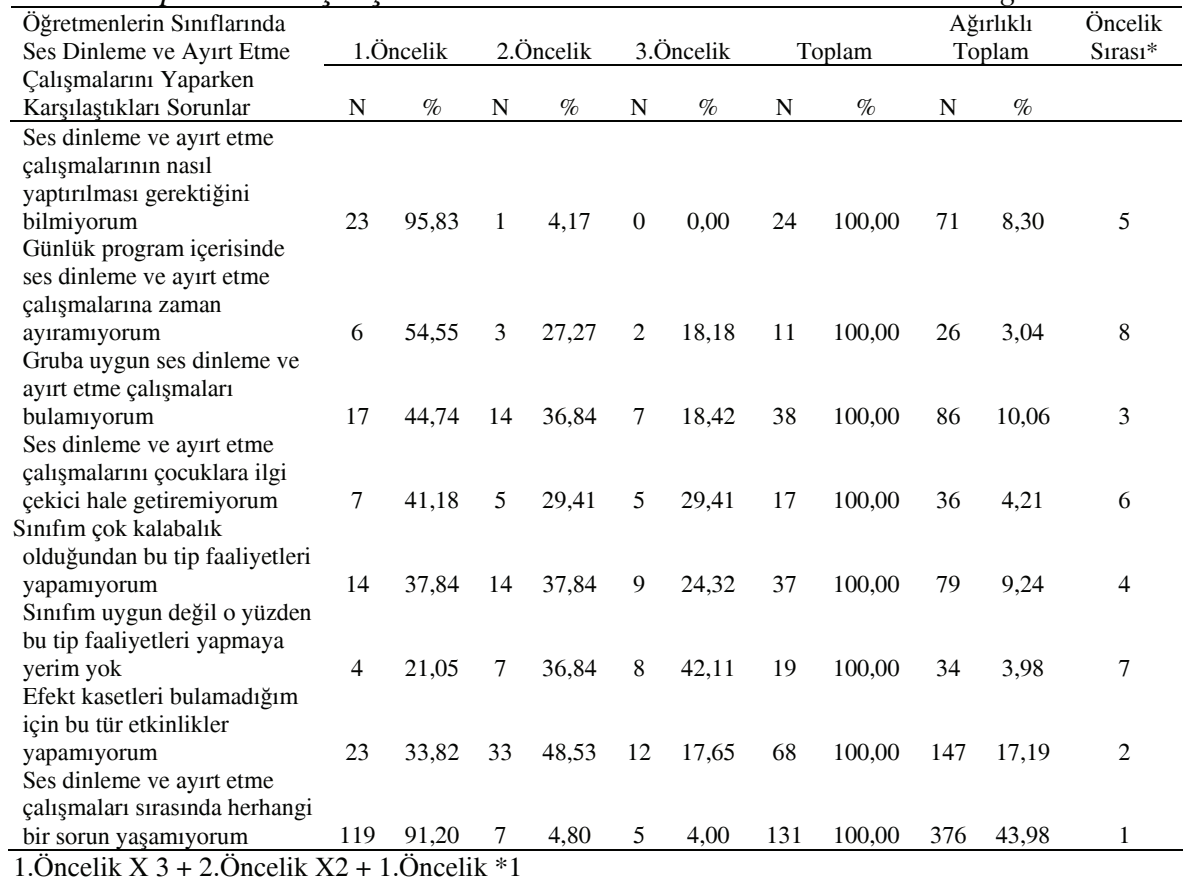


Öğretmenlerin \% 43,98' i 1 . öncelikle ses dinleme ve ayırt etme çalışmaları sırasında herhangi bir sorun yaşamadıklarını, \% 17,19' u 2. öncelikle efekt kasetleri olmadığını, \% 10,06' s1 ise 3. öncelikle gruba uygun ses dinleme ve ayırt etme çalışmaları bulamadıkları için bu tür etkinlikleri yapamadığını belirtmişlerdir.

Tablo 10. Ö ̆gretmenlerin Sınıflarında Müzikli Hikaye Çalışmalarını Yapma Biçimlerinin Öncelik Sırasına Göre Dă̆ılımı

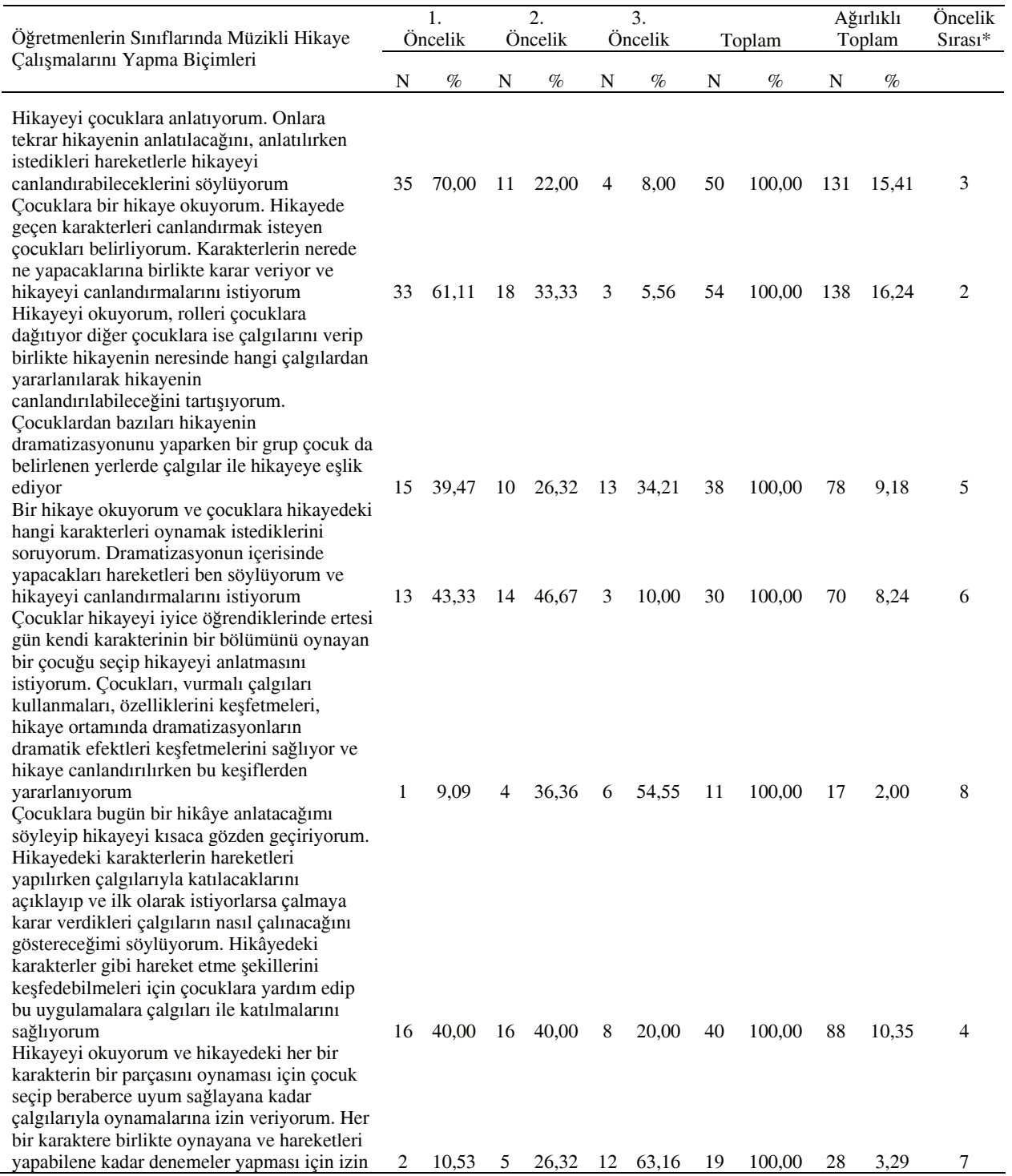


veriyorum. Denemeler boyunca, hikayede

kendi melodileri süresince yalnızca hareket

edeceklerini söylüyorum. Çocuklara bu

ipuçlarını yakalayamadıklarında daha fazla

hatırlatma yapiyorum.

Sınıfımda müzikli hikaye çalışmaları

yapmiyorum

1.Öncelik X $3+2$. Öncelik X2 + 1.Öncelik *1

Öğretmenlerin \% 35,29 u 1 . öncelikle sinıfında müzikli hikaye çalışmaları yapmadığını, \% 16,24' ü 2. öncelikle çocuklara bir hikaye okuduklarını hikayedeki karakterleri canlandırmak isteyen çocukları belirleyip hikayeyi canlandırmalarını istediklerini, $\% 15,41^{\prime}$ i ise 3 . öncelikle hikayeyi çocuklara anlatırken istedikleri hareketlerle hikayeyi canlandırabileceklerini söylediklerini belirtmişlerdir.

Tablo 11. Ö ğretmenlerin Sınıflarında Müzikli Hikaye Çalışmalarını Yaparken Karşılaştıkları Sorunların Öncelik Sırasına Göre Dă̆ılımı

\begin{tabular}{|c|c|c|c|c|c|c|c|c|c|c|c|}
\hline \multirow{2}{*}{$\begin{array}{l}\text { Öğretmenlerin Sınıflarında } \\
\text { Müzikli Hikaye Çalışmalarını } \\
\text { Yaparken Karşılaştıkları } \\
\text { Sorunlar }\end{array}$} & \multicolumn{2}{|c|}{ 1.Öncelik } & \multicolumn{2}{|c|}{ 2.Öncelik } & \multicolumn{2}{|c|}{ 3.Öncelik } & \multicolumn{2}{|c|}{ Toplam } & \multicolumn{2}{|c|}{$\begin{array}{c}\text { Ağırlıklı } \\
\text { Toplam }\end{array}$} & \multirow[t]{2}{*}{$\begin{array}{l}\text { Öncelik } \\
\text { Sıras1* }\end{array}$} \\
\hline & $\mathrm{N}$ & $\%$ & $\mathrm{~N}$ & $\%$ & $\mathrm{~N}$ & $\%$ & $\mathrm{~N}$ & $\%$ & $\mathrm{~N}$ & $\%$ & \\
\hline $\begin{array}{l}\text { Müzikli hikaye çalışmalarının } \\
\text { nasıl yaptırılması gerektiğini } \\
\text { bilmiyorum. }\end{array}$ & 90 & 100,00 & 0 & 0,00 & 0 & 0,00 & 90 & 100,00 & 270 & 34,22 & 1 \\
\hline $\begin{array}{l}\text { Günlük program içerisinde } \\
\text { zaman bulamıorum }\end{array}$ & 6 & 60,00 & 3 & 30,00 & 1 & 10,00 & 10 & 100,00 & 25 & 3,17 & 9 \\
\hline $\begin{array}{l}\text { çalışmaları bulamıyorum } \\
\text { çuzikli hikaye çalışmalarını } \\
\text { çlara ilgi çekici hale }\end{array}$ & 28 & 77,78 & 4 & 11,11 & 4 & 11,11 & 36 & 100,00 & 96 & 12,17 & 3 \\
\hline $\begin{array}{l}\text { getiremiyorum } \\
\text { Sınıfim çok kalabalık }\end{array}$ & 6 & 50,00 & 3 & 25,00 & 3 & 25,00 & 12 & 100,00 & 27 & 3,42 & 8 \\
\hline $\begin{array}{l}\text { olduğundan bu tip faaliyetleri } \\
\text { yapamıyorum }\end{array}$ & 5 & 16,13 & 22 & 70,97 & 4 & 12,90 & 31 & 100,00 & 63 & 7,98 & 4 \\
\hline $\begin{array}{l}\text { Sınıf ortamım uygun değil o } \\
\text { yüzden bu tip faaliyetleri } \\
\text { yapmaya yerim yok }\end{array}$ & 8 & 25,81 & 8 & 25,8 & 15 & 48,39 & 31 & 100,00 & 55 & 6,97 & 7 \\
\hline Yeterli müzik kasetim yok & 8 & 27,59 & 12 & 41,38 & 9 & 31,03 & 29 & 100,00 & 57 & 7,22 & 6 \\
\hline $\begin{array}{l}\text { Müzikli dramatizasyon için } \\
\text { uygun hikaye bulamıyorum } \\
\text { Müzikli drama çalışmaları } \\
\text { sırasında herhangi bir sorun } \\
\text { yaşamıyorum }\end{array}$ & 11 & 36,67 & 9 & 30,00 & 10 & 33,33 & 30 & 100,00 & 135 & 7,73 & 5 \\
\hline
\end{tabular}

Öğretmenlerin \% 34,22' si 1. öncelikle müzikli hikaye çalışmalarının nasıl yaptırılması gerektiğini bilmediğini, $\% 17,11$ ' i 2 . öncelikle müzikli drama çalışmaları sırasında herhangi bir sorun yaşamadığını, \% 12,17' si ise 3. öncelikle gruba uygun müzikli drama çalışmaları bulamadığını ifade etmiştir. 
Tablo 12. Ö ğretmenlerin Sınıflarında Yaratıcı Dans Çalışmalarını Yapma Biçimlerinin Öncelik Sırasına Göre Dă̆ılımı

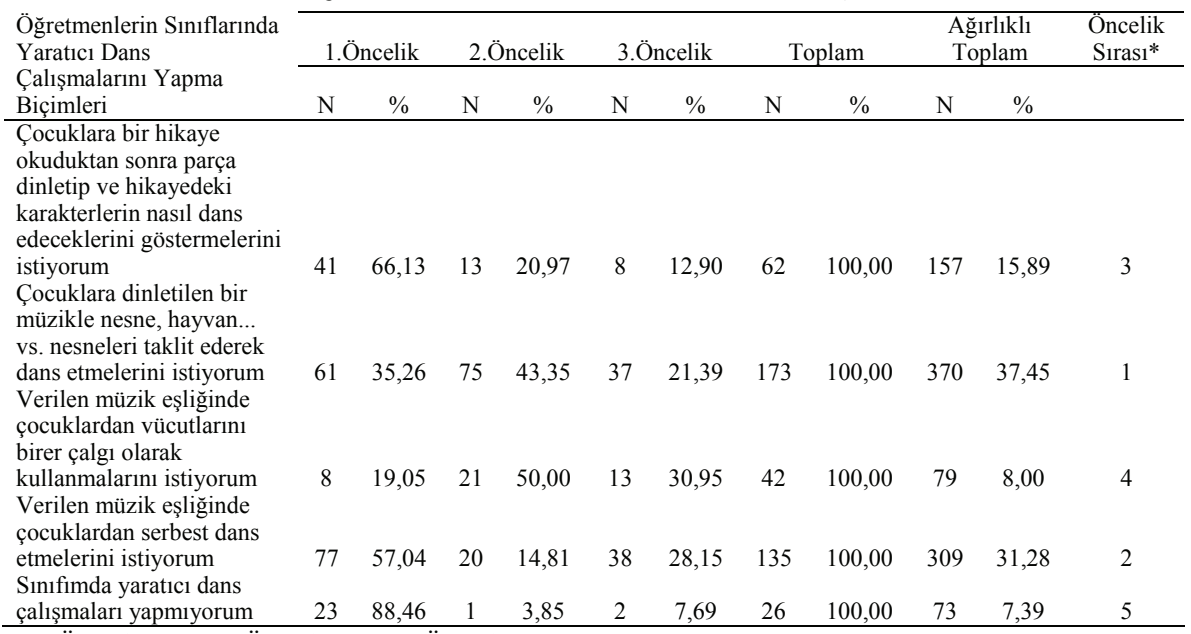

*1.Öncelik X $3+2$.Öncelik X2 + 1.Öncelik *1

Öğretmenlerin \% 37,45’i 1. öncelikle çocuklara bir parça dinletip dans ederken çevrelerindeki bazı nesneleri taklit ederek dans etmelerini istediklerini, \% 31,28' i ise 2. öncelikle müzik eşliğinde serbest dans etmelerini istedikleri ve \% 15,89' u ise 3. öncelikle çocuklardan bir obje, bir hayvan ya da hikayedeki karakterleri taklit ederek yaratıcı dans etmelerini desteklediklerini belirtmişlerdir.

Tablo 13. Öğretmenlerin Sınıflarında Yaratıcı Dans Çalışmaları Yaparken Karşılaştıkları Sorunların Öncelik Sırasına Göre Dă̆ılımı

\begin{tabular}{|c|c|c|c|c|c|c|c|c|c|c|c|}
\hline \multirow{2}{*}{$\begin{array}{l}\text { Öğretmenlerin Sınıflarında } \\
\text { Yaratıcı Dans Çalışmaları } \\
\text { Yaparken Karşılaştıkları } \\
\text { Sorunlar }\end{array}$} & \multicolumn{2}{|c|}{ 1.Öncelik } & \multicolumn{2}{|c|}{ 2.Öncelik } & \multicolumn{2}{|c|}{ 3.Öncelik } & \multicolumn{2}{|c|}{ Toplam } & \multicolumn{2}{|c|}{$\begin{array}{l}\text { A ğırlıklı } \\
\text { Toplam }\end{array}$} & \multirow[t]{2}{*}{$\begin{array}{l}\text { Öncelik } \\
\text { Siras1* }\end{array}$} \\
\hline & $\mathrm{N}$ & $\%$ & $\mathrm{~N}$ & $\%$ & $\mathrm{~N}$ & $\%$ & $\mathrm{~N}$ & $\%$ & $\mathrm{~N}$ & $\%$ & \\
\hline $\begin{array}{l}\text { Yaratıcı dans çalışmalarının } \\
\text { nasıl yaptırılması gerektiğini } \\
\text { bilmiyorum }\end{array}$ & 20 & 83,33 & 0 & 0,00 & 4 & 16,67 & 24 & 100,00 & 64 & 7,72 & 5 \\
\hline $\begin{array}{l}\text { Günlük program içerisinde } \\
\text { yaratıcı dans çalışmalarına } \\
\text { zaman bulamıyorum }\end{array}$ & 8 & 80,00 & 0 & 0,00 & 2 & 20,00 & 10 & 100,00 & 26 & 3,14 & 8 \\
\hline $\begin{array}{l}\text { Gruba uygun yaratıcı dans } \\
\text { çalışmaları bulamıyorum }\end{array}$ & 9 & 36,00 & 10 & 40,00 & 6 & 24,00 & 25 & 100,00 & 53 & 6,39 & 6 \\
\hline $\begin{array}{l}\text { Ş̧ıctiremiyorum } \\
\text { Sınım çok kalabalık }\end{array}$ & 5 & 38,46 & 4 & 30,77 & 4 & 30,77 & 13 & 100,00 & 27 & 3,26 & 7 \\
\hline $\begin{array}{l}\text { olduğundan bu tip faaliyetleri } \\
\text { yapamiyorum }\end{array}$ & 10 & 23,26 & 20 & 46,51 & 13 & 30,23 & 43 & 100,00 & 83 & 10,01 & 4 \\
\hline $\begin{array}{l}\text { Sınıf ortamım uygun değil o } \\
\text { yüzden bu tip faaliyetleri } \\
\text { yapmaya yerim yok } \\
\text { Yeterli müzik kaset, teyp, }\end{array}$ & 9 & 17,65 & 19 & 37,25 & 23 & 45,10 & 51 & 100,00 & 88 & 10,62 & 3 \\
\hline $\begin{array}{l}\text { CD çalar ve CD' im yok } \\
\text { Yaratıcı dans çalışmaları } \\
\text { yaparken her hangi bir sorun }\end{array}$ & 41 & 60,29 & 20 & 29,41 & 7 & 10,29 & 68 & 100,00 & 170 & 20,51 & 2 \\
\hline yaşamiyorum & 102 & 93,58 & 5 & 4,59 & 2 & 1,83 & 109 & 100,00 & 318 & 38,36 & 1 \\
\hline
\end{tabular}

1.Öncelik X $3+2$. Öncelik X2 + 1. Öncelik *1 
Yaratıcı dans çalışmaları sırasında öğretmenlerin yaşadıkları sorunlar incelendiğinde, 1. sırada $(\% 38,36)$ öğretmenler yaratıcı dans çalışmaları yaparken her hangi bir sorun yaşamadıklarını belirtirlerken 2. sırada (\% 20,51) yeterli müzik kaset, teyp, CD çalar ve CD'lerinin bulunmadığını, 3 . sırada ise $(\%$ 10,62) sınıf ortamı uygun olmadığ yapılamadığını vurgulamışlardır.

Tablo 14. Öğretmenlerin Sınıflarında Ritim Çalışmalarını Yapma Biçimlerinin Öncelik Sırasına Göre Dağılımı

\begin{tabular}{|c|c|c|c|c|c|c|c|c|c|c|c|}
\hline \multirow{2}{*}{$\begin{array}{l}\text { Öğretmenlerin Sınıflarında Ritim } \\
\text { Çalışmalarını Yapma Biçimleri }\end{array}$} & \multicolumn{2}{|c|}{ 1.Öncelik } & \multicolumn{2}{|c|}{ 2.Öncelik } & \multicolumn{2}{|c|}{ 3.Öncelik } & \multicolumn{2}{|c|}{ Toplam } & \multicolumn{2}{|c|}{$\begin{array}{l}\text { A ğırlıklı } \\
\text { Toplam }\end{array}$} & \multirow[t]{2}{*}{$\begin{array}{l}\text { Öncelik } \\
\text { Sırasi* }\end{array}$} \\
\hline & $\mathrm{N}$ & $\%$ & $\mathrm{~N}$ & $\%$ & $\mathrm{~N}$ & $\%$ & $\mathrm{~N}$ & $\%$ & $\mathrm{~N}$ & $\%$ & \\
\hline $\begin{array}{l}\text { Verdiğim ritimle çocukların } \\
\text { yürüme, koşma, zıplama gibi } \\
\text { vücudun doğal } \\
\text { hareketlerini yapmalarını } \\
\text { istiyorum } \\
\text { Daha önceden belirlemiş olduğum } \\
\text { ritim kalıplarını davul, tef gibi } \\
\text { vurmalı çalgılarla çalıyorum ve } \\
\text { çocukların da aynı ritimi } \\
\text { çıkarmalarını istiyorum }\end{array}$ & 120 & 86,96 & 12 & 8,70 & 13 & 4,35 & 138 & 100,00 & 390 & 35,20 & 1 \\
\hline $\begin{array}{l}\text { Şarkıları ritim eşliğinde } \\
\text { söyletiyorum }\end{array}$ & 33 & 34,02 & 32 & 32,99 & 32 & 32,99 & 97 & 100,00 & 195 & 17,60 & 2 \\
\hline $\begin{array}{l}\text { Çocuklara çalgılar vererek } \\
\text { oyunları içinde yeni ritim kalıpları } \\
\text { yaratmalarını istiyorum }\end{array}$ & 4 & 10,81 & 17 & 45,95 & 16 & 43,24 & 37 & 100,00 & 62 & 5,60 & 6 \\
\hline $\begin{array}{l}\text { Çocuklara yavaş ve hızlı ritimler } \\
\text { veriyorum, onlardan da aynı } \\
\text { ritimleri tutmalarını istiyorum }\end{array}$ & 5 & 10,20 & 29 & 59,18 & 15 & 30,61 & 49 & 100,00 & 88 & 7,94 & 5 \\
\hline $\begin{array}{l}\text { Çocukların bedenlerini kullanarak } \\
\text { ( ellerini birbirine vurma, parmak } \\
\text { şıklatma...vs.) ritim tutmalarını } \\
\text { istiyorum }\end{array}$ & 13 & 21,67 & 17 & 28,33 & 30 & 50,00 & 60 & 100,00 & 103 & 9,30 & 4 \\
\hline $\begin{array}{l}\text { Şarkı sözlerini başka ritimlere } \\
\text { uydurmalarını istiyorum } \\
\text { El çırparak çocuklara ritmik bir } \\
\text { şekilde sorular soruyorum } \\
\text { çocukların da aynı ritimle el } \\
\text { çırparak sorularıma cevap } \\
\text { vermelerini bekliyorum }\end{array}$ & 0 & 0,00 & 1 & 16,67 & 21 & 83,33 & 33 & 100,00 & 50 & 0,63 & 9 \\
\hline $\begin{array}{l}\text { Sınıfımda ritim çalışmaları } \\
\text { yapmıyorum }\end{array}$ & 9 & 100,0 & 0 & 0,0 & 0 & 0,0 & 9 & 100 & 27 & 2,4 & 8 \\
\hline
\end{tabular}

* 1.Öncelik X 3 + 2.Öncelik X2 + 1.Öncelik *1

Öğretmenlerin \% 35,20'si ritim çalışmalarında 1. öncelikli olarak ritim vermekte ve çocukların bu ritimle yürümesini, koşmasını, zıplamasını istemektedirler. $\% 17,600^{\prime} \quad 12$ 2. Öncelikli olarak çocukların şarkıları ritim eşliğinde söylemesini, \% 16,79' u ise 3 . öncelikli olarak belirli ritim kalıplarını çalgıyla çalıp çocukların da aynısını vurmasını istediklerini belirtmişlerdir. 
Tablo 15. Öğretmenlerin Sinıflarında Ritim Çalışmaları Yaparken Karşılaştıkları Sorunların Öncelik Sirasina Göre Dă̆gllımı

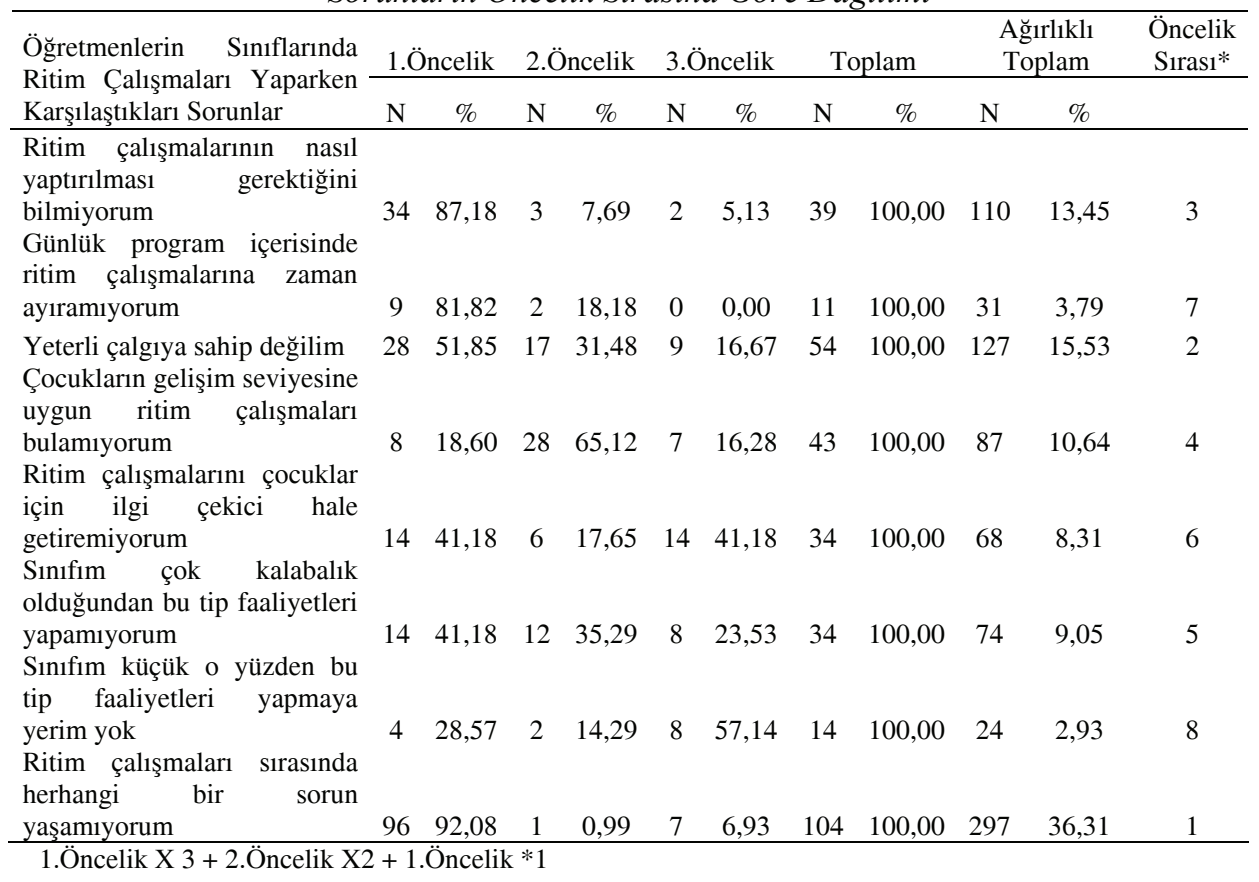

Öğretmenlerin \% 36,31' i 1. öncelikli olarak ritim çalışmaları sırasında herhangi bir sorun yaşamadıklarını, \% 15,53' ü 2. öncelikli olarak yeterli çalgıya sahip olmadıklarını, \% 13,45' $\mathrm{i}$ ise 3. öncelikli olarak ritim çalışmalarının nasıl yaptırılması gerektiğini bilmediklerini ifade etmişlerdir.

Tablo 16. Ögrretmenlerin Genel Olarak Okul Öncesinde Müzik Eğitimi Konusunda Kendilerini Nasıl Bulduklarına İlişkin Görüşlerinin Dă̆̆llımı

\begin{tabular}{lcc}
\hline Müzik eğitimine ilişkin olarak & N & $\%$ \\
\hline Kendimi yeterli bulmuyorum & 27 & 12,74 \\
Kendimi orta düzeyde yeterli buluyorum & 140 & 66,04 \\
Kendimi yeterli buluyorum & 45 & 21,22 \\
\hline Toplam & 212 & 100,00 \\
\hline
\end{tabular}

Öğretmenlerin \% 66,04' ü kendisini müzik eğitiminde orta düzeyde yeterli bulurken, $\% 21,22$ ' si kendini müzik eğitiminde yeterli bulmuştur. $\% 12,74$ ' ü ise kendini müzik eğitimi konusunda yeterli bulmamıştır. 


\section{TARTIŞMA VE SONUÇ}

Araştırmaya dahil olan 212 anasınıfı öğretmeninden anket yoluyla elde edilen bulgular incelendiğinde; öğretmenlerin \% 82, 55' i lisans mezunudur, $\%$ 80,66' s1 müzik eğitimi konusunda hizmet içi eğitime gereksinim duymaktadırlar. Öğretmenlerin müzik eğitimi konusunda hizmet içi eğitime ihtiyaç duymalarının nedeni, lisans eğitimi sırasında aldıkları eğitimin sınırlı olmasından kaynaklanabilir. Bu nedenle bu konuda daha fazla bilgiye ve uygulamaya gereksinim duyuyor olabilirler. Öğretmenlerin \% 93,40' ının sinıfında bir müzik köşesi bulunduğu, ancak \% 57, 08' inin müzik eğitimi sırasında çalgı kullanmadığı görülmektedir.

Öğretmenlerin sınıflarındaki müzik köşesinde bulunan çalgılar incelendiğinde (Tablo 6), \% 94,34' ünde marakas, \% 85,85' inde tef, \% 69,34' ünde davul, \% 68,40' inda zil, \% 58,49' unda ritim çubuğu, \% 41,98' inde parmak zilleri ve çelik üçgen, \% 37,74' ünde ksilofon, $\% 22,17$ ' sinde metalofon, \% 14,15' inde kastanyet, \% 11,79' unda ses kutuları bulunmaktadır. Bunların yanı sıra öğretmenlerin \% 0,94' ünün sınıfında glockensipel, \% 0,47' sinde ise kum kağıdı blokları bulunmaktadır. Okul öncesi eğitim kurumlarının müzik köşelerinde glockensipel' den ve kum kağıdı bloklarından çok az oranda bulunması, bu çalgıların çok fazla bilinmediğini ya da onları satın almada sıkıntıların olduğunu düşündürmektedir. Bununla beraber marakas ve tefin her sınıfta bulunması ise bu çalgıların genellikle tüm oyuncakçılarda satılıyor olmasından veya artık malzemelerle kolayca yapılabiliyor olmasından kaynaklanabilir. Nitekim Turla (1995)' nın yapmış olduğu araştırmaya göre, öğretmenlerin çalgı olarak öncelikle tefi (\% 68. 40) ve ardından da marakası (\% 63.60) tercih ettikleri görülmektedir. Altaş'ın (2006) yaptığı araştırmaya göre ise, anasınıflarındaki müzik köşelerinde bulunan çalgılar; marakas $(\% 79,1)$, tef $(\% 78,2)$, trampet ve ritim çubukları $(\% 42,7)$ şeklindedir. Bu bulgular araştırma bulguları ile benzerlik göstermektedir.

Öğretmenlerin \% 44,34' ünün sınıfında her çocuğa yetecek kadar çalgı bulunurken, \% 55,66' sının sınıfında her çocuğa yetecek sayıda çalgı bulunmamaktadır (Tablo 7). Okul öncesi eğitim kurumlarında çalgı yetersizliğinin nedeni, maddi yetersizliklerden ya da önceliklerin farklı köşe ve etkinlikler üzerinde olmasından kaynaklanabilir. Jeong (2005) ve Sığırtmaç (2006) tarafından yapılan araştırmalarda da birçok okul öncesi eğitim kurumunda müzik eğitimi için çalgıların yetersiz olduğu saptanmıştır. $\mathrm{Bu}$ bulgular da araştırma bulguları ile benzerlik göstermektedir.

Öğretmenlerin \% 36,74' ü ses dinleme ve ayırt etme çalışmalarında 1. öncelikli olarak çocuklara çevredeki doğal sesleri (araba sesi, sokaktaki gürültüler vb) dinletip bu seslerin kaynağını sorduklarını, \% 30,33' ü 2 . 
öncelikli olarak çeşitli ses efektleri (hayvan, doğa, eşya sesleri vb.) dinletip çocuklardan bu seslerin ne sesleri olduğunu bulmalarını istediklerini, \% 11,96' s1 ise 3. öncelikli olarak çocukların kendi bedenlerini kullanarak ses çıkarmalarını (elleriyle karnına vurması, başına vurması gibi) ve bu seslerin bedenlerinin hangi bölümünden geldiğini bulmalarını istediklerini belirtmişlerdir (Tablo 8). Bununla beraber, öğretmenlerin \% 43,98' i 1. öncelikle ses dinleme ve ayırt etme çalışmaları sırasında herhangi bir sorun yaşamadıklarını, \% 17,19' u 2. öncelikle efekt kasetleri olmadığını, \% 10,06 ' s1 ise 3. öncelikle gruba uygun ses dinleme ve ayırt etme çalışmaları bulamadıkları için bu tür etkinlikleri yapamadıklarını vurgulamışlardır (Tablo 9).

Öğretmenlerin \% 35,29’ u 1. öncelikle sınıfında müzikli hikaye çalışmaları yapmadığını, \% 16,24' ü 2. öncelikle çocuklara bir hikaye okuduklarını hikayedeki karakterleri canlandırmak isteyen çocukları belirleyip hikayeyi canlandırmalarını istediklerini, \% 15,41' i ise 3. öncelikle hikayeyi çocuklara anlatırken istedikleri hareketlerle hikayeyi canlandırabileceklerini söylediklerini belirtmişlerdir (Tablo 10). Turla (1995), tarafından yapılan araştırmada öğretmenlerin müzikli hikayelere daha az önem verdikleri belirlenmiştir (\% 25, 00). Bu bulgu, araştırma bulgularını destekler niteliktedir. Bununla beraber, öğretmenlerin \% 34,22' si 1. öncelikle müzikli hikaye çalışmalarının nasıl yaptırılması gerektiğini bilmediğini, $\% 17,11$ ' i 2 . öncelikle müzikli drama çalışmaları sırasında herhangi bir sorun yaşamadığını, \% 12,17' si ise 3. öncelikle gruba uygun müzikli drama çalışmaları bulamadığını ifade etmiştir (Tablo 11). Nitekim Tablo 10 verileri ile birlikte bu durum değerlendirildiğinde müzikli hikaye çalışmalarını kullanmayan öğretmenlerin bu etkinliklerin nasıl yapıldığ konusunda yeterli bilgi ve birikime sahip olmamalarından dolayı bu tür etkinlikleri tercih etmedikleri söylenebilir.

Öğretmenlerin \% 37,45'i 1. öncelikle çocuklara bir parça dinletip dans ederken çevrelerindeki bazı nesneleri taklit ederek dans etmelerini istediklerini, \% 31,28' i ise 2. öncelikle müzik eşliğinde serbest dans etmelerini istediklerini ve \% 15,89' u ise 3. öncelikle çocuklardan bir obje, bir hayvan ya da hikayedeki karakterleri taklit ederek yaratıcı dans etmelerini istediklerini belirtmektedirler (Tablo 12). Yaratıc1 dans çalışmaları sırasında öğretmenlerin yaşadıkları sorunlar incelendiğinde, öğretmenler 1. sırada $(\% 38,36)$ yaratıcı dans çalışmaları yaparken her hangi bir sorun yaşamadıklarını belirtirlerken 2 . sırada $(\%$ 20,51) yeterli müzik kaset, teyp, CD çalar ve CD'lerinin bulunmadığını, 3. sırada ise $(\% 10,62)$ sınıf ortamı uygun olmadığı için bu tip etkinliklerin yapılamadığını belirtmişlerdir (Tablo 13). Öğretmenlerin günümüzde müzik, kaset, CD çalar veya CD' lerinin bulunmadığını belirtmeleri ilginç bir bulgudur. Nitekim 
internet ortamında tüm bu belirtilen materyallere ulaşılabilmektedir. Dolayısıyla temel sorunun öğretmenlerin bilgi ve uygulama eksikliğinden kaynaklandığı söylenebilir. Zira Sı ̆̆ırtmaç (2006)' in çalışma sonuçları da bu bulguyu destekler niteliktedir.

Öğretmenlerin \% 35,20'si ritim çalışmalarında 1. öncelikli olarak ritim vermekte ve çocukların bu ritimle yürümesini, koşmasını, zıplamasını istemektedir. \% 17,60' 12 2. öncelikli olarak çocukların şarkıları ritim eşliğinde söylemesini, \% 16,79' u ise 3. öncelikli olarak belirli ritim kalıplarını çalgıyla çalıp çocukların da aynısını vurmasını istemektedir (Tablo 14).

Öğretmenlerin \% 36,31' i 1. öncelikli olarak ritim çalışmaları sırasında herhangi bir sorun yaşamadığını, \% 15,53' ü 2. öncelikli olarak yeterli çalgıya sahip olmadığını, $\% 13,45^{\prime}$ i 3 . öncelikli olarak ritim çalışmalarının nasıl yaptırılması gerektiğini bilmediğini belirtmiştir (Tablo 15).

(Tablo 16) Öğretmenlerin \% 66,04' ü kendisini müzik eğitiminde orta düzeyde yeterli bulurken, $\% 21,22$ ' si ise kendisini müzik eğitiminde yeterli bulmuşlardır. \% 12,74' ü ise müzik eğitimi konusunda kendilerini yeterli bulmamışlardır. Nitekim, öğretmenlerin \% 66,04' ünün kendilerini orta düzeyde yeterli bulmaları bu konudaki donanımlarını yeterli görmemelerinden kaynaklanabilir. Zira araştırma bütünü ile değerlendirildiğinde de öğretmenlerin yanıtlarından aynı kanıya varmak mümkündür. Öğretmenlerin çok bilinen uygulamaları tercih etmeleri farklı uygulamalara yönelmemeleri de bunun bir sonucu olabilir. Dolayısıyla öğretmenlerin müzik eğitimi sırasında yapılan uygulamalar hakkında bilgilendirilmesi, yeniliklerden haberdar edilmesi kaçınılmaz görülmektedir.

\section{KAYNAKLAR}

Altaş, B. (2006). “Anasınıfı Öğretmenlerinin Müzik Eğitimine Yönelik Algıladıkları Yeterlilikler ve Müzik Eğitimi Ortamına Yönelik Düşünceleri." Yayımlanmamış yüksek lisans tezi, Marmara Üniversitesi Eğitim Bilimleri Enstitüsü, İstanbul.

Artan, İ. (1993). “Anaokuluna Devam Eden 54- 77 Aylık Çocuklara Seslerle İlgili Becerilerin Kazandırılmasında Müzik Uygulamalarının Etkisinin İncelenmesi." Yayımlanmamış doktora tezi, Hacettepe Üniversitesi Sağlık Bilimleri Enstitüsü, Ankara.

Artan, İ. (2003). Okul Öncesi Dönemde İşitsel Algının Geliştirilmesi. M. Sevinç (Ed.) Gelişim ve Eğitimde Yeni Yaklaşımlar. (ss. 273- 281) İstanbul: Morpa Kültür Yayınları LTŞ. 
Çetin, Ç, G. (2006). Etkinliklerle Müzik Öğretimi, Müzik, Hayat Bilgisi, Fen ve Teknoloji, Matematik, Türkçe Dersleri Kazanımlarıly Müzik Öğretimi,. Ankara: Kök Yayıncılık.

Deasy, R. J. (2002). Learning in the Arts and Student Academic and Social Development. Art Education Partnership. ERIC veri tabanından 14.11.2007 tarihinde alınmıştır. pp:171.ED466-413-SO-033- 941.

Eliason, C. and Jenkıns, L. (2003). A Practical Guide to Early Childhood Curriculum. (Seventh Edition). New Jersey: Merrill Prentice Hall.

Gürgen, E. T. (2006). Müzik Eğitiminde Yaratıcılığ 1 Geliştiren Yöntem ve Yaklaşımlar, İnönü Üniversitesi Ĕ̆itim Fakültesi Dergisi, 7 (12) 8193.

Henniger, M. L. (1999). Teaching Young Children an Introduction. New Jersey: Merrill Prentice Hall.

Hirsh, R. A. (2004). Early Childhood Curriculum, Incorporating Multiple Intelligences, Developmentally Appropriate Practice, and Play. Pittsburg. Pennsylvania: Pearson.

Isenberg, J. P. and Jalongo, M. R. (1997). Creative Expressin and Play in Early Childhood, (Second Edition.). New Jersey: Merrill Prentice Hall.

Jeong, J. (2005). "Adaptation of Dalcroze Methodology to the Teaching of Music to Kindergarden Students in Koreo." Ph.D. Thesis, Boston University.

Kostelnik, M. J., Soderman, A. K. and Whiren, A. P. (2004). Developmentally Appropriate Curriculum. (Third Edition.). New Jersey: Merrill Prentice Hall.

Machado, M. J. (2003). Early Childhood Experiences in Language Arts Emerging Literacy. Canada:Thomson.

Özkardeş, O. G. (2005). Okul Öncesi Eğitim Kurumlarında Müziğin Kullanımı. A. Oktay, Ö. P. Unutkan (Ed.). Okul Öncesi Ĕ̆itimde Güncel Konular. (ss. 266- 277). İstanbul: Morpa Kültür Yayınları LTŞ.

Schellenberg, E. G. (2005). Music and Cognitive Abilities. American Psychological Society. 14 (6) 317- 320.

Schlaug, G., Norton, A., Overy, K. and Winner, E. (2005). Effects of Music Training on The Child's Brain And Cognitive Development. New York Academy of Sciences. 1060, 219- 230.

Sığırtmaç, A. D. (2006). Müzik Eğitimi İle Gelen Akademik Başarı. O. Ramazan, K. Efe, ve G. Güven (Ed.). Marmara Üniversitesi Eğitim Fakültesi 1. Uluslar Arası Okul Öncesi Ĕ̆itim Kongresi Bildiri Kitabı. III. Cilt. (ss.190- 194). İstanbul Ya- Pa San A.Ş.

Sümbüloğlu, V. ve Sümbüloğlu, K. (1998). Sağllk Bilimlerinde Araştırma Yöntemleri. Ankara: Hatiboğlu Yayınevi. 
Taylor, B. J. (1999). A Child Goes Forth, A Curriculum Guide for Preschool Children, Ninth Edition, New Jersey: Prentice- Hall.

Tselentis, C. M. (2000). "Effective Teachıng Practices in a Preschool Music and Movement Program: an Observational Study." MS. Thesis, University of Arizona.

Turla, A. (1995). "Okulöncesi Eğitim Kurumlarında Görev Yapan Öğretmenlerin Sanat Etkinliklerini Planlama, Uygulama ve Değerlendirme Becerilerinin İncelenmesi.” Yayımlanmamış yüksek lisans tezi, Hacettepe Üniversitesi Sağlık Bilimleri Enstitüsü, Ankara.

Yıldız, G. (2003). Çocuklarda Müziksel Gelişim. Eğitim Araştırmaları Dergisi. 10, 184- 191.

Wilson, A. (2006). Creativity in Primary Education. Glasgow: Learning Matters. 